\title{
THE REASONABLENESS AND EFFECTIVENESS OF THE AMENDMENT TO SECTION 26 OF THE MAINTENANCE ACT 99 OF 1998
}

\author{
B Batchelor \\ BCOM (Law) LLB LLM \\ LLD Candidate, University of Fort Hare
}

SUMMARY

Section 26 of the Maintenance Act as amended by the Maintenance Amendment Act 38 of 2005 (hereinafter "Amendment Act") is a key provision for enforcing maintenance orders in South Africa. Underpinning this provision is the need to ensure that children are protected from destitution and deprivation due to maintenance defaulters. Primarily, this section limits a maintenance defaulter's access to credit by negatively affecting his or her credit rating. The utility and legality of this provision as a measure of enforcing maintenance orders has yet to be judicially tested in South Africa. Therefore, this article evaluates the reasonableness of the limitation of a maintenance payer's fundamental rights in the light of foreign jurisdiction mechanisms for enforcing maintenance orders.

\section{INTRODUCTION}

Children's rights and welfare receive significant recognition under international and domestic law. ${ }^{1}$ The Convention on the Rights of the Child, ${ }^{2}$ to which South Africa is a state party, requires state parties to recognise the right of every child to a standard of living, which is adequate for the child's physical, mental, moral, spiritual and social development. ${ }^{3}$ The Convention also requires state parties to take all appropriate measures in order to secure the recovery of maintenance for the child from the parents or other persons having financial responsibility for the child. ${ }^{4}$

See United Nations Convention on the Rights of the Child, General Assembly Resolution $44 / 25$ of 20 November 1989 hereinafter "the Convention"; World Declaration on the Survival, Protection and Development of Children 1990; and African Charter on the Rights and Welfare of the Child, 1990.

2 lbid.

3 Article 27(1) of the Convention.

4 Article 27(4) of the Convention; Article 18 of the African Charter on Human and Peoples Rights, adopted 27 June 1981, OAU Doc. CAB/LEG/67/3 rev. 5, 21 I.L.M. 58 (1982), entered into force on the $21^{\text {st }}$ of October 1986, Article 4 and 20 (b) of the African Charter on 
Children have a right to maintenance, which stems from the common law and has further been entrenched in the Constitution, ${ }^{5}$ enshrined in the Children's Act ${ }^{6}$ and enforced through the Maintenance Act (hereinafter "the Act") respectively. ${ }^{7}$ However, despite the provision of the right to maintenance for children, in reality many children are deprived of it and accordingly marginalised due to non-adherence of maintenance orders and their ineffective enforcement. This means any improvement to amend the Act and including enforcement of the abovementioned laws should seek to eradicate the marginalisation of children who are not receiving adequate support from their parents or guardians.

Due to the ineffectiveness of the implementation and enforcement of maintenance orders, the Act was recently amended by the Maintenance Amendment Act (hereinafter "Amendment Act") ${ }^{8}$ in order to, inter alia, provide for the reporting of a maintenance defaulter to any business, which has as its objective the granting of credit, or is involved in the credit rating of persons. ${ }^{9}$ Arguably, this amendment limits a maintenance payer's right to privacy and dignity. The efficacy of this amendment as a measure to enforce maintenance payments and the reasonableness of the limitation upon fundamental rights caused by such amendment has not been explored or judicially tested in South Africa. This article seeks to evaluate the reasonableness of the limitation of a maintenance payer's fundamental rights and the effectiveness of the amendment to section 26 of the Act by analysing foreign jurisdiction's mechanisms of enforcement of maintenance orders in comparison with South Africa's enforcement mechanisms.

In order to assess the efficacy of the amendment and the reasonableness of the purported limitation imposed, this paper will: firstly review the enforcement mechanisms in the Act; secondly, discuss the amendment to section 26, particularly its implication on constitutional rights; and thirdly,

the Rights and Welfare of the Child was adopted by the Organization of African Unity (OAU) in 1990 (in 2001, the OAU legally became the African Union (AU) and was entered into force in 1999).

5 S 28(1)(b) and (c) of the Constitution provides every child the right to family care or parental care and to basic nutrition, shelter, basic health care services and social services read together with s 233 of the Constitution "Application of International Law": "When interpreting any legislation, every court must prefer any reasonable interpretation of the legislation that is consistent with international law over any alternative interpretation that is inconsistent with international law".

638 of 2005.

799 of 1998. The Maintenance Act applies in respect of the legal duty of any person to maintain any other person, irrespective of the nature of the relationship between those persons giving rise to that duty. See s 2(1) of the Maintenance Act. The Maintenance Act 1998 came into operation on the $26^{\text {th }}$ of November 1999, except for ss $5,7(1)$ (d) and $7(2)$, which contain the provisions concerning maintenance investigators. These provisions were put into operation on the $1^{\text {st }}$ of November 2006. The Maintenance Act of 1963 was the predecessor of the current Maintenance Act. See De Jong "Ten-Year Anniversary of the Maintenance Act 99 of 1998 - A Time to Reflect on Improvements, Shortcomings and the Way Forward" 2009 SALJ 259 par 2 for a brief discussion of the Maintenance Act of 1963. See also Cronjé and Heaton South Africa Family Law (1999) 69-78, for the differences between the Maintenance Act of 1963 and 1998.

89 of 2015

9 See s 26(2A) of the Act. 
examine enforcement mechanisms in the foreign jurisdictions of Namibia, Canada and the United Kingdom by drawing lessons from such foreign jurisprudence. Looking at these jurisdictions will expose the strengths and weaknesses/inconsistencies in the South African maintenance enforcement system and suggest possible solutions.

\section{ENFORCEMENT OF MAINTENANCE ORDERS}

A maintenance order is defined as any order for the payment ${ }^{10}$ of a sum of money towards the maintenance of any person issued by any court in South Africa, and includes, except for the purposes of section $31,{ }^{11}$ any sentence suspended on condition that the convicted person, make payment of the sums of money towards the maintenance of any other person. ${ }^{12}$ The Act provides both civil $^{13}$ and criminal $^{14}$ remedies for failure to comply with a maintenance order. ${ }^{15}$ Civil remedies include execution against property, the attachment of emoluments and the attachment of debts. ${ }^{16}$ In terms of the Act, any order made by a maintenance court has the effect of an order made in a civil action. ${ }^{17}$ This infers that maintenance and arrear maintenance may thus, like any other civil debt, also be enforced in the ordinary courts and not necessarily in terms of the Act. ${ }^{18}$ The Amendment Act recently included civil sanction, namely, reporting the maintenance defaulter to the credit bureau. ${ }^{19}$

A defaulting maintenance debtor may also be charged with the crime of failing to make a payment in accordance with a maintenance order. ${ }^{20}$ If the accused raises the defence that his or her failure was due to lack of means, ${ }^{21}$ he or she will not be acquitted if it is proved that the failure was due to his or her misconduct or unwillingness to work. ${ }^{22}$ The court may order

This includes periodical payments.

1 S 31 deals with offences relating to maintenance orders.

12 See $\mathrm{s} 1$ of the Act. The Act also allows the maintenance court to make an order for the payment of maintenance by way of a once-off lump sum. See Meyer "The 1998 Maintenance Act: An Improvement on its Predecessor?” Judicial Officer 121122.

13 See ch 5 of the Act.

14 See ch 6 of the Act.

15 The remedies created in the Act are regarded as sui generis since they span from both civil and criminal law.

16 S 26(1) read with ss 27-30 of the Act.

$17 \mathrm{~S} 24(1)$ of the Act.

18 De Jong 2009 SALJ 595.

19 It is noteworthy that reporting maintenance defaulters to credit bureau could be viewed as a form of sanction. Whether such a sanction is justified in a democratic state such as South Africa remains a question to be explored in this paper.

20 See s 31(1) of the Act. See also Mamashela "The Courts' Interpretation of S 31 of the Maintenance Act 99 of 1998 and its Predecessors" 2005 SALJ 217; and Carnelley "A Review of the Criminal Prosecution and Sentencing of Maintenance Defaulters in South Africa, Commentary on Sentencing Strategies" 2012 SACJ 349-351.

21 The defence of means must be investigated even if the accused does not raise it. See $S v$ Morekhure 2000 (2) SACR 730 (T). The onus of proving lack of means is not discharged if the accused merely shows that his or her salary was reduced. See MS $v$ KS 2012 (6) SA $482(\mathrm{KZP})$

$22 \mathrm{~S} 31(2)$. The state bears the onus of proving that the failure was due to the accused's unwillingness to work or his or her misconduct. See $S v$ Nduku 2000 (2) SACR 382 (Tk). Cf 
that arrear maintenance, as well as interest on the arrears be recovered from a convicted maintenance debtor, and execution may be taken against his or her property. ${ }^{23}$ Ignoring a maintenance order constitutes contempt of court for which the maintenance defaulter can be committed to prison. Contempt of court proceedings are a recognised method of pressurising a maintenance defaulter to comply with his/her obligation. ${ }^{24}$

A review of the literature indicates that children often struggle to access maintenance due to inefficiencies in the system, inadequate resources and capacity. ${ }^{25}$ In Bannatyne $v$ Bannatyne (Commission of Gender Equality, as Amicus Curiae $)^{26}$ the Constitutional Court pointed out that the legislative remedies of the maintenance court were totally ineffective to protect the rights of women and the best interests of children. The court found that logistical difficulties in the Maintenance Courts frustrate the good intentions of the Act. Various maintenance debtors who can afford to pay maintenance have been shown to brazenly evade the enforcement mechanism in the Act. $^{27}$

It is submitted that the Act is an improvement on the maintenance laws that preceded it and the former has had a progressive impetus on the protection of disempowered women and vulnerable children. However, evidence indicates that the enforcement of maintenance orders is far from being perfect. ${ }^{28}$ This, conceivably calls for a generous assessment of some of the new enforcement measures recently introduced in the Act, in this case, section $26(2 \mathrm{~A})$.

\section{SECTION 26(2A) OF THE ACT}

Section 26 of the Act is amended by the addition of subsection (2A), which reads as follows:

"On the granting of an application contemplated in subsection (2) by a maintenance court, the maintenance officer or clerk of the court at the request of the maintenance officer, shall, notwithstanding anything to the contrary

s 3 of the Maintenance Act of 1963, which provided that an accused that raised the defence of lack of means had the onus to prove same.

$23 \mathrm{~S} 40(1)$ and (2) of the Act.

24 Sparks v Sparks 1998 (4) SA 714 (W) $725 \mathrm{H}$.

25 A qualitative research was undertaken in 2009 to evaluate the strengths and weaknesses of the Maintenance Act, ten years since it come into operation. See De Jong 2009 SALJ 59-609. See also De Jong and Sephai "New Measures to Secure Maintenance Payments for Disempowered Women and Vulnerable Children" 2014 THRHR 195 198-201; Carnelley 2012 SACJ 344; and Moyo "Assessing the Effectiveness of the Maintenance Act's Provision for Attachment of Emoluments" in Budlender and Moyo (eds) What about Children? The Silent Voices in Maintenance (2004) 57.

2620032 BCLR 111 (CC) (hereinafter "Bannatyne" case).

27 For instance, in $A G \vee D G 2017$ (2) SA 409 (GJ), the respondent was a multimillionaire, director and member of several companies, yet claimed to be unemployed. He was a serial defaulter on maintenance payments and had several court orders against him, but he frustrated their execution by contrived challenges to attachments and by switching funds out of the affected accounts. He was concealing his assets and had engineered a decrease in salary purely to frustrate the court order.

28 Ibid. 
contained in any law, in the prescribed manner, furnish the particulars of the person against whom a maintenance order has been made and a certified copy of the order of the court contemplated in subsection (2)(a)(i), (ii) or (iii), to any business, which has as its object the granting of credit or is involved in the credit rating of persons."

Section 26(2A) of the Act contains a crucial amendment to the Act in respect of the enforcement of maintenance orders. ${ }^{29} \mathrm{~A}$ maintenance officer ${ }^{30}$ is, in terms of section $26(2 \mathrm{~A})$ of the Act, obliged to furnish the personal particulars of the maintenance defaulter to credit bureaux and other businesses, which grant credit or are involved in the credit rating of persons as soon as a complaint is made in terms of section $26 .{ }^{31}$ In terms of regulation 17 of the National Credit Regulations of the National Credit Act, ${ }^{32}$ once a maintenance defaulter has a judgment on his or her credit profile, such information will be listed on his/her credit profile until, a court rescinds the judgment. ${ }^{33}$ Before section 26(2A) became effective, maintenance officers held the discretion to make such reports to credit bureaux in terms of section 31(4) of the Act only after a maintenance defaulter had been convicted of an offence under section 31 of the Act. The object of this provision is to prevent a maintenance defaulter from continuing to receive credit at an early stage in order to ensure that he/she does not incur further obligations, which would affect his/her ability to meet maintenance obligations. ${ }^{34}$ It is noteworthy that section 31(4) of the Act has now been amended to oblige maintenance officers to report a convicted defaulter to credit bureaux and removes the discretion whether or not to do so. ${ }^{35}$ As a result of the aforementioned amendments, credit providers are now required, during their pre-agreement assessment, to ascertain whether the prospective consumer has maintenance obligations. ${ }^{36}$ Section $26(2 \mathrm{~A})$ of the Act does not only ensure that credit is not extended to persons who cannot afford it but also encourages maintenance debtors to honour their obligations if they intend to maintain a positive credit profile.

Some scholars have criticised this provision on the basis that it may lead to blacklisting of a maintenance defaulter, thereby denying him or her an opportunity to enter into credit agreements, which may further reduce the financial resources from which maintenance could be paid. ${ }^{37} \mathrm{~A}$ question can thus be posed as to whether reporting credit defaulters to credit bureaux, credit providers, and credit rating agencies, is tantamount to "[k]illing the

29 De Jong and Sephai 2014 THRHR 212.

30 Maintenance officer means any person who is deemed to have been appointed as a maintenance officer in terms of $\mathrm{s} 4(1)$ (a) or who is appointed under $\mathrm{s} 4(2)$, as the case may be. See $\mathrm{s} 1$ of the Act.

De Jong and Sephai 2014 THRHR 212.

34 of 2005 (hereinafter the "NCA").

33 See National Credit Regulations GN R202 in GG 38557 of 2015-03-13.

34 De Jong and Sephai 2014 THRHR 212; and Heaton and Kruger South African Family Law 4ed (2015) 52.

35 De Jong and Sephai 2014 THRHR 212.

36 See s 81(2) of the NCA. See also Van Heerden and Renke "Perspectives on the South African Responsible Lending Regime and the Duty to Conduct Pre-Agreement Assessment as a Responsible Lending Practice" 2015 International Insolvency Review 67-95.

37 Heaton and Kruger South African Family Law 57 fn 137. 
goose that lays the golden eggs". ${ }^{38}$ A further question that may possibly be raised is whether section $26(2 \mathrm{~A})$ of the Act constitutes unreasonable state intervention into the private affairs of a maintenance defaulter. In other words, "making a credit bureau reporting of maintenance defaulters obligatory and introducing credit bureau reporting of maintenance debtors at a much earlier stage may infringe their rights to privacy and to have their dignity protected". 39 However, it is important to note that failure to pay maintenance undermines the rights of children protected in terms of section 28 of the Constitution. Weighing the rights of maintenance defaulters' vis-ávis the rights of children in determining whether the aforementioned rights can be limited in terms of section 36 of the Constitution is therefore imperative. $^{40}$

In addition, concerns were raised regarding the difficulty by credit bureaux in obtaining maintenance judgments. This was raised specifically in relation to the fact that these judgments also contain certain confidential information pertaining to minors. ${ }^{4}$ The Department of Trade and Industry (DTI) and the Department of Justice and Constitutional Development noted prior to the finalisation of the new National Credit Act Regulations ${ }^{42}$ that since the courts do not have a process to filter out the confidential information of minors, the bureaux cannot access the documents. ${ }^{43}$ This difficulty for credit bureaux to uplift the information from judgments may lead credit providers to increase the cost of credit or refuse access to credit altogether in situations where they are not certain as to the credit risk of consumers. It is therefore recommended that a process to filter out confidential information of minors be implemented in order to avoid delays in effectively implementing section $26(2 \mathrm{~A})$ of the Act.

\section{Balancing of competing rights and interests}

The process of determining whether a limitation of a right is reasonable and justifiable within the contemplation of section 36 of the Constitution involves the balancing of competing at times also conflicting interests. It entails taking

38 The South Africa Law Reform Commission (SALRC) used this phrase in relation to s 11(1) of the repealed Maintenance Act 23 of 1963, which provided for a charge of fine or imprisonment (or both) against a maintenance defaulter. See SALRC Issue Paper 5: Project 100: Review of the Maintenance System par 311.

39 See De Jong and Sephai 2014 THRHR 213. The rights to "human dignity" and "privacy" are enshrined in ss 10 and 14 of the Constitution respectively.

40 S 36 of the Constitution: "Limitation of rights (1) The rights in the Bill of Rights may be limited only in terms of law of general application to the extent that the limitation is reasonable and justifiable in an open and democratic society based on human dignity, equality and freedom, taking into account all relevant factors, including - (a) the nature of the right; (b) the importance of the purpose of the limitation; (c) the nature and extent of the limitation; (d) the relation between the limitation and its purpose; and (e) less restrictive means to achieve the purpose. (2) Except as provided in subsection (1) or in any other provision of the Constitution, no law may limit any right entrenched in the Bill of Rights."

41 Arde "Maintenance Defaulters will Battle to Get Credit" 6 June 2015 http://www.iol.co.za/personal-finance/maintenance-defaulters-will-battle-to-get-credit1868328 (accessed 2017-04-10).

42 GN R202 in GG 38557 of 2015-03-15.

43 Ibid. 
account of the considerations enumerated in section 36 of the Constitution. This process has been described as a proportionality analysis. ${ }^{44}$ In $S v$ Makwanyane ${ }^{45}$ Chaskalson $\mathrm{P}$ held, pertaining to the application of the then limitation clause in section 33 of the Interim Constitution, that: ${ }^{46}$

"The limitation of constitutional rights for a purpose that is reasonable and necessary in a democratic society involves the weighing up of competing values, and ultimately an assessment based on proportionality. This is implicit in the provisions of section 33(1). The fact that different rights have different implications for democracy, and in the case of our Constitution, for 'an open and democratic society based on freedom and equality', means that there is no absolute standard which can be laid down for determining reasonableness and necessity. Principles can be established, but the application of those principles to particular circumstances can only be done on a case by case basis. This is inherent in the requirement of proportionality, which calls for the balancing of different interests. In the balancing process, the relevant considerations will include the nature of the right that is limited, and its importance to an open and democratic society based on freedom and equality; the purpose for which the right is limited and the importance of that purpose to such a society; the extent of the limitation, its efficacy, and particularly where the limitation has to be necessary, whether the desired ends could reasonably be achieved through other means less damaging to the right in question".

\section{Courts' interpretation of section 28 of the Constitution in re: enforcement of maintenance orders}

Although section $26(2 \mathrm{~A})$ of the Act has not been subjected to constitutional scrutiny before a court of law, it is important to examine the principles that our courts have established in interpreting and applying section 28 of the Constitution in relation to the enforcement of maintenance orders. Section 28 of the Constitution entitled "Children" inter alia protects the rights of the child to maintenance. ${ }^{48}$ In terms of section $28(2)$, "[a] child's best interests are of paramount importance in every matter concerning the child". 49 As far as maintenance of children is concerned, the courts have held that they have a duty in terms of section 28(2) of the Constitution to protect the best interests of children from maintenance debtors who are likely to shirk their future maintenance responsibilities and that the High Court is empowered to order enforcement by way of remedies that fall outside the ambit of the Act. ${ }^{50}$

44 Phillips v Director of Public Prosecutions 2003 (4) BCLR 357 (CC) par 22.

451995 (3) SA 391 (CC) (hereinafter "Makwanyane").

46 Constitution of the Republic of South Africa 200 of 1993 (hereinafter "the interim Constitution").

47 Makwanyane par 104. See also National Coalition for Gay and Lesbian Equality v Minister of Justice 1999 (1) SA 6 (CC) 31; Phillips v Director of Public Prosecutions supra 365; and Johncom Media Investments Ltd v M 2009 (4) SA 7 (CC) par 24.

48 See Currie and De Waal The Bill of Rights Handbook 6ed ch 27 for a comprehensive discussion of children's rights.

49 For a further exposition on the concept of the "best interest" of the child see "The Best Interests of Children in the South African Constitution" 2006 International Journal of Law Policy and the Family 27.

50 Heaton and Kruger South African Family Law 54. 
The courts have specifically cited the Constitutional Court's decisions in Bannatyne and Fose $v$ Minister of Safety and Security ${ }^{51}$ in support of the extension of the enforcement of a maintenance debtor's obligations towards his or her children. ${ }^{52}$ In Fose ${ }^{53}$ the Constitutional Court emphasised the court's duty to ensure that effective relief is granted for the infringement of a constitutional right.

The Constitutional Court in Bannatyne dealt with the issue whether the High Court had jurisdiction to order contempt of court on the grounds that the respondent had failed to comply with a maintenance order made by the Magistrate's Court. ${ }^{54}$ Mokgoro $\mathrm{J}$ referred to difficulties in Maintenance Courts, which results in the maintenance system not functioning properly and the rule of law being adversely affected. She held that:

"Systemic failures to enforce maintenance orders have a negative impact on the rule of law. The courts are there to ensure that the rights of all are protected. The Judiciary must endeavour to secure for vulnerable children and disempowered women their small but life sustaining legal entitlements. If court orders are habitually evaded and defied with relative impunity, the justice system is discredited and the constitutional promise of human dignity and equality is seriously compromised for those dependent on the law".

Mokgoro further held that the Maintenance Courts and laws are important mechanisms to give effect to children's rights, and that failure to ensure the effective operation of the maintenance system amounts to a failure to protect children. Effective mechanisms for the enforcement of maintenance obligations were, therefore "essential for the simultaneous achievement of

51 Supra.

52 For discussions of some of the cases, which indicate that maintenance for children is increasingly viewed as a children's rights issue; see Moodley in Sloth-Nielsen and Du Toit (eds) Trials and Tribulations, Trends and Triumphs: Developments in International African and South African Child and Family (2008) 188; Abrahams and Matthews Promoting Children's Rights in South Africa: A Handbook for Members of Parliament (2011) 21.

53 Supra.

At the time of the divorce, a court made a maintenance order that included medical expenses in respect of each of a man's two children and an order for rehabilitative maintenance in respect of the wife. Before a year had gone by, the ex-husband had failed to comply with this order and requested a reduction in the amount of maintenance. Although the reduction was granted, he defaulted again. When his ex-wife approached the court to enforce the maintenance order, he paid the arrears maintenance, but again stopped paying after a few months. He then unilaterally reduced the amount of maintenance in respect of the children and refused to pay their medical expenses as agreed, after which he stopped paying completely. The ex-wife approached the court for an order that his assets be sold in execution to pay his maintenance debt, but two writs of execution failed to produce any assets. It appears that he had "sold" his assets to his girlfriend. Subsequently, the exhusband again applied for a reduction of the maintenance order, but when his ex-wife opposed it, he somehow had the matter removed from the court roll without her notice. In desperation, she applied for an order of imprisonment for contempt of court, which the High Court granted, but on appeal, was dismissed on the basis that she had not exhausted all her legal remedies before applying for imprisonment. The ex-husband was in fact capable of paying maintenance, but deliberately used legal technicalities and processes to avoid doing so. He could afford legal representation, and after the contempt proceedings were initiated, he offered to pay arrears maintenance of R34,000 on condition that the matter was withdrawn. He threatened to have himself sequestrated if the ex-wife did not withdraw the contempt proceedings. See Bannatyne par 7-16.

55 Bannatyne par 27. 
the rights of the child and promotion of gender equality"..$^{56}$ The Constitutional Court in this matter implied, by way of granting the process in aid, that section 26 of the Act is not a numerus clausus and extended the enforcement possibilities available to the courts, holding that the intention of the legislature was not to restrict the remedies contained in the Act. ${ }^{57}$ Mokgoro $\mathrm{J}$ called upon lower courts "to be alive to recalcitrant maintenance defaulters who use legal processes to side-step their obligations towards their children". ${ }^{58}$ This demonstrates that the lower courts should adopt a much stricter attitude towards maintenance defaulters. ${ }^{59}$

Various courts received the decision of Bannatyne with great enthusiasm. In compliance with its constitutional duty to afford effective relief to children whose best interests were being violated by a recalcitrant maintenance debtor, the High Court in Mngadi $v$ Beacon Sweets and Chocolates Provident Fund ${ }^{\text {ob }}$ ordered a provident fund to retain the lump sum withdrawal benefit of the children's future maintenance. Nicholson $\mathrm{J}$ held that:

"[The Constitution required that the order be made because to] refuse the present application would be to further undermine the rights of children and disempowered women [while to] grant the application will be to thwart an unreasonable, intransigent father who has no respect for the provisions of the Maintenance Court order or his common-law duties to maintain his own kith or kin".

56 Supra par 28.

57 Bannatyne par 21. See also Hoctor and Carnelley "Maintenance Arrears and the Rights of the Child: S v November 2006 (1) SACR 213 (C)" 2007 Journal of South African Law 119 200.

58 Bannatyne par 32.

59 Bonthuys "Realizing South African Children's Basic Socio-Economic Claims against Parents and the State: What Courts can Achieve" 2008 International Journal of Law, Policy and the Family 333337.

60 [2003] 2 All SA 279 (D) (hereinafter "Mngadi").

61 Mngadi $v$ Beacon Sweets and Chocolates Provident Fund supra 289B-C, 398D-E, 287D, 396D-E, 287D, 396D-E. In Magewu v Zozo [2004] 3 All SA 235 (C) par 15 (hereinafter "Magewu") the court made a similar order to that in Mngadi, to respect the pension withdrawal benefit of a maintenance debtor who had been retrenched despite the fact that he was not in maintenance arrears. Citing a history of difficulties in extracting maintenance from the maintenance debtor and the State's duty to ensure a functioning system for the enforcement of maintenance orders the court held that:

"The Maintenance Act does not create a closed list of mechanisms available in law to assist children who have claims of maintenance and their specific situations are not expressly set out in the Act. S 2(2) of the Maintenance Act provides that it may not be interpreted so as to derogate from the common law duty of support relating to the liability of persons to maintain other persons. In this instance, it is clear that the Applicant's case may not fall flat due to the fact that the First Respondent is not currently in arrears. Nicholson $\mathrm{J}$ correctly set out that courts may not adopt a non possumus approach where a fund is available and may be used to secure the right to maintenance for children. See Mngadi supra 287A. In any event, there seems to be no reason, in logic, why such an order should not be made having regard to the best interest of the child". In this case, the father had resigned from his job in order to escape paying maintenance. He was not in arrears at the time of the present order but had been in arrears in the past. The court found that if he were allowed to withdraw his provident fund benefit he would most probably "either secrete it away, spend it on himself or otherwise dissipate it" and would not "nurture it carefully and preserve it to perform his maintenance obligations". 
Van Zyl J in Soller v Maintenance Magistrate, Wynberg ${ }^{62}$ agreed with the arguments made by Mokgoro $\mathrm{J}$ in Bannatyne that the Act clearly does not provide for all the remedies that Maintenance Courts may be called upon to grant, in which event innovative remedies should be considered. They would certainly be justified if the rights and the best interests of a child, which are securely entrenched in section 28 of the Constitution, should be infringed or threatened.

According to the Parliamentary Monitoring Group (PMG), the Deputy Minister of Justice and Constitutional Development stated that there is a difference between an ordinary debtor and a maintenance defaulter. The Deputy Minister stated further that the legal obligation of parents to maintain their children is more serious than the obligation to pay an ordinary debt. ${ }^{63}$ Therefore, maintenance defaulters themselves should realise that maintenance obligations are different from other financial obligations in that the money is generally for immediate personal needs such as shelter, food and clothing, among other things. ${ }^{64}$ Thus, maintenance should be regarded as life-sustaining money relied upon for survival and, as such, the maintenance obligation must always be regarded as a primary obligation. ${ }^{65}$

In light of the above discussion, it is clear that the courts are willing to interpret the section 28 rights of the child to provide the widest possible relief available for disempowered vulnerable children and women in order to ensure expedient and effective enforcement of maintenance orders in their favour. ${ }^{66}$ The courts may receive section $26(2 \mathrm{~A})$ of the Act as the muchneeded innovation to encourage capable maintenance debtors to fulfil their obligations. It is doubtful that serial maintenance defaulters will be able to successfully invoke their rights to privacy and dignity against section 26(2A) of the Act. The courts seem to be stringent when it comes to maintenance defaulters who employ chicanery and deceit to the detriment of vulnerable children and women.

\section{A BRIEF COMPARATIVE ANALYSIS OF MAINTENANCE ENFORCEMENT}

\section{Canadian case: Westendorp v Westendorp ${ }^{67}$}

The Ontario Superior Court of Justice found that the suspension of a maintenance defaulter's driver's license did not amount to an infringement of his fundamental rights under sections 7, 11 and 15 of the Canadian Charter of Rights and Freedoms in the Constitution Act of 1982. In casu, Mr Westendorp was in arrears with spousal support payments. His driver's license was suspended in terms of Part $V$ of Ontario's provincial Family

622006 (2) SA 66 par 29.

63 Arde http://www.iol.co.za/personal-finance/maintenance-defaulters-will-battle-to-get-credit1868328 (accessed 2017-04-10).

64 Hoctor and Carnelley 2007 Journal of South African Law 200.

65 Ibid.

66 Cf De Jong and Sephai 2014 THRHR 216.

672000 CanLII 22650 (ON SC) (hereinafter “Westendorp”). 
Responsibility and Support Arrears Enforcement Act, 1996 after he failed to comply fully with a notice from the Family Responsibility Office. The notice had requested him to pay off the arrears, enter into a repayment plan with the Family Responsibility Office or obtain a refraining order, which would prohibit the suspension of his license. ${ }^{6}$

Mr Westendorp subsequently requested the court to strike down Part $\mathrm{V}$ of the Act because it violates the Canadian Charter of Rights and Freedoms. $\mathrm{He}$ argued that this Part of the Act does not provide for a hearing prior to the suspension of the license, is discriminatory against maintenance debtors, denies them proper legal safeguards, and is contrary to the values of a free and democratic society. Relying on section 15(1) of the Charter, he also claimed a constitutional right to drive where necessary in order to earn a living. ${ }^{69}$ Section 15(1) of the Charter provides that every individual is equal before and under the law and has the right to equal protection and equal benefit of the law without discrimination and, in particular, without discrimination based on race, national or ethnic origin, colour, religion, sex, age or mental or physical disability. ${ }^{70}$ Mr Westendorp argued that because the court has the power to imprison a maintenance debtor in certain circumstances, ${ }^{71}$ this was a criminal or quasi-criminal process that entitles him to a hearing on the merits of whether his license should be suspended.

The court firstly found that none of the listed grounds in section 15 or any analogous grounds were applicable in this case. ${ }^{72}$ With respect to the alleged lack of procedural safeguards, the court found that Part $\mathrm{V}$ of the Act does provide for a complete procedural code for the suspension of defaulters' licenses. It permits a defaulter to avoid the suspension by entering into an agreement with the Director of the Family Responsibility Office regarding compliance with the support order and the payment of arrears. The Act also permits a defaulter to obtain an order ceasing the suspension of the driver's license. ${ }^{73}$ The court further found that there is no entitlement in the circumstances to a hearing on the merits of whether the license should be suspended. The court found that the so-called "right to drive" is not a liberty protected by section 7 of the Charter. ${ }^{74}$

Although Mr Westendorp attempted to distinguish his case by stating that the right to drive is protected if earning a living is necessary, the court stated that the rights intended to be protected by section 7 of the Charter do not include a right of an economic character. ${ }^{75}$ For all of these reasons, his claim to strike down Part $\mathrm{V}$ of the Act was dismissed. ${ }^{76}$

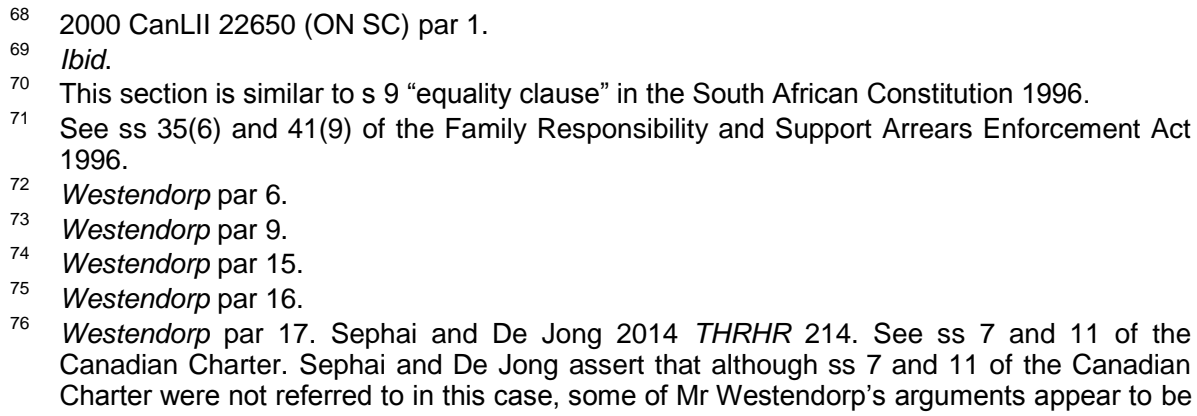

76 Westendorp par 17. Sephai and De Jong 2014 THRHR 214. See ss 7 and 11 of the Canadian Charter. Sephai and De Jong assert that although ss 7 and 11 of the Canadian Charter were not referred to in this case, some of Mr Westendorp's arguments appear to be 


\section{An evaluation of the lessons for South Africa}

It is important to note that many of the arguments presented in the above decision could also be applied to the South African context. ${ }^{77}$ The right to enforce a maintenance order through suspending a maintenance defaulter's driver's license triumphed over a defaulter's fundamental right to freedom. In light of this decision and the provisions of the South African Bill of Rights, a limitation of respondents' fundamental rights in order to secure for vulnerable children their life-sustaining legal entitlements would, depending on the circumstances of a specific case, almost certainly be deemed reasonable and justifiable. The harm caused by the infringement of respondents' fundamental rights is minor in comparison to the beneficial purpose that the limitation is designed to achieve. The fact that section 26(2A) of the Act, as a new measure to ensure that women and children receive the maintenance that is due to them, may infringe respondents' fundamental rights should therefore not be seen as a bar to introducing and implementing this measure. $^{78}$

By declining to declare Part $\mathrm{V}$ of the Act inconsistent with the Canadian Charter of Rights and Freedoms, the judgment shows that Canadian Courts are willing to interpret law in a manner that is supportive of the country's own enforcement of maintenance orders, and by extension safeguarding the best interest of the child. In delivering the judgment, the Canadian Court emphasized that courts are there to ensure that the rights of all are protected. This means that the judiciary must endeavour to secure for vulnerable children and disempowered women their small but life sustaining legal entitlements. Linking the foregoing submission to the statutory obligation of furnishing the personal particulars of maintenance defaulters to credit bureaux, it can be argued that such a requirement is reasonable because it prevents maintenance defaulters from becoming overindebtedness until they clear their maintenance arrears.

\section{Enforcement of maintenance orders in Namibia}

In Namibia, the Maintenance Act of $2003^{79}$ was put in place to, inter alia, provide for the payment and enforcement of maintenance as well as to repeal the Maintenance Act of $1963 .^{80}$ This Act applies to any relationship where a person has a legal duty to maintain another. ${ }^{81}$ Under the 2003

directed at these sections of the Charter. ${ }^{76}$ The Canadian Charter inter alia provides everyone the right to life, liberty and security; any person charged with an offence, the right not to be compelled to be a witness in proceedings against that person in respect of the offence; and the right to be presumed innocent until proven guilty according to law in a fair and public hearing by an independent and impartial tribunal.

77 See De Jong and Sephai 2014 THRHR 215.

78 Cf Sephai and De Jong 2014 THRHR 215-216.

799 of 2003. See Hubbard and Cassidy "Family Reform in Namibia: Work in Progress" 2002 International Survey of Family Law 255 par E, for a brief discussion of the events that took place before the enactment of the Namibian Maintenance Act.

S 2 of Act 9 of 2003. 
Maintenance Act, the court can grant the parent applying for maintenance an order to receive maintenance in kind (goats or cattle) where the father is not employed but owns livestock. ${ }^{82}$ The Maintenance Act of Namibia, like that of South Africa, provides for both civil and criminal mechanisms to enforce maintenance orders. ${ }^{83}$

Although the maintenance reforms are in their embryonic stages, Namibia is one country that is also contemplating reporting maintenance defaulters to credit bureaux and credit providers. In striving to address child poverty in Namibia, the Women Action for Development (WAD) is calling upon lawmakers to amend the Namibian Maintenance Act to prohibit maintenance defaulters from accessing credit and loans in the credit market until they settle maintenance payments. Salatiel Shinedima, WAD Executive Director, noted that WAD believes that prohibition against maintenance defaulters from accessing credit and loans will help reduce the high percentage of child poverty in the country. ${ }^{84}$ He stated that the National Household Income and Expenditure Survey of 2009/10 indicates that thirty-four percent of Namibian children are poor as compared to the twenty-nine percent of the general population. Shinedima believes that children are more vulnerable to poverty than adults are as they depend on adults for their well-being. ${ }^{85}$ He advocates that defaulting on child maintenance should become a social disgrace on guilty parents and invoke the wrath of the community, as affected children eventually become the responsibility of the state to support. Although it seems blacklisting maintenance defaulters is gaining attention, as a mechanism to encourage maintenance debtors to honour their obligations, time will tell whether the Namibian Parliament will incorporate such provisions in the Maintenance Act of 2003.

\section{An evaluation of the lessons for South Africa}

The above discussions relating to Namibia touched on pertinent aspects of maintenance law reform. It has demonstrated that one of the methods available for maintenance recovery in Namibia is the right of the person applying for maintenance to be granted an order by the court to receive maintenance in kind (goats or cattle) where the maintenance defaulter is not employed but owns livestock. This innovative approach together with the proposal to report maintenance defaulters to credit bureau will enhance enforcement of maintenance orders. Such an approach will help to bridge the maintenance system lacunae emanating from both legislative lacunae as well socio economic factors. In South Africa, socio-economic factors must be

82 S 17(4). See also Hinz and Mapaure "Legal Pluralism and the Apartheid Past: Challenges to Namibian Family Law Reform and Development" 2009 International Survey of Family Law 301303.

83 See part VII and VIII of Act 9 of 2003. See also Izack $v$ State (CA/15/2013) [2013] NAHCMD 207 (23 July 2013); Kauvee $v$ Kauvee 2014 (NACHMD) 161 (22 May 2014); and Hamukwanya v Hamukwanya 2013 (NACHMD) 201 (18 July 2013).

84 Lela "Blacklist Maintenance Defaulters: WAD" (04 September 2015) http://www.lelamobile.com/content/54619/Blacklist-maintenance-defaulters-WAD/ (accessed 2017-04-06).

85 lbid. 
considered when determining whether the current maintenance system is defective. Such socio-economic factors include poverty, unemployment and limited state resources. It is noteworthy that in South Africa poverty remains one of the greatest challenges limiting a creditor's right to claim maintenance from a debtor when he or she is unemployed. However, in Mngadi v Beacon Sweets and Chocolate Provident Fund ${ }^{86}$ the court maintained that purposeful unemployment will not permit defaulting in maintenance payments.

\section{Enforcement of maintenance in the United Kingdom}

Enforcement of child maintenance obligations has been a contentious and highly dynamic policy area in the United Kingdom. ${ }^{87}$ Since 1991, child maintenance policy has been continually amended by three successive governments who have all searched for a solution to the problem of ensuring that non-resident parents (maintenance debtors) make regular payments of child maintenance to support their children, where they can afford to do so. ${ }^{88}$ Child maintenance compliance rates in the United Kingdom have been

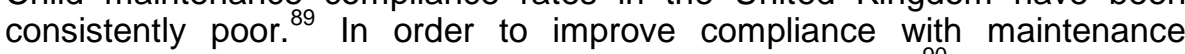
payments, the Child Support Agency (hereinafter "CSA") ${ }^{90}$ and the Child Maintenance Service (hereinafter "CMS") have been given an ever-

2004 (5) SA 388 (D).

87 Skinner "Child Maintenance in the United Kingdom" 2012 European Journal of Social Security 231.

88 These changes include the Child Support Act of 1991; Child Support, Pensions and Social Security Act 2000; Child Maintenance and Other Payments Act of 2008 (CMOPA); and the Welfare Reform Act of 2012. For further discussion of these Acts, see Skinner 2012 European Journal of Social Security $233 \mathrm{ff}$.

89 Skinner 2012 European Journal of Social Security 245.

90 The Child Support Act of 1991 established the CSA, a centralized body that assumed responsibility for "the assessment, review, collection, and enforcement of maintenance payments." The CSA had the power "to collect information on incomes and obligations, make a legally binding assessment of what amount of [support] was payable, determine methods of payment, monitor and (where necessary) collect maintenance and enforce payment where payments failed." Importantly, the CSA, rather than the courts, managed all child support issues and disputes; the 1991 Act intended to reduce judicial involvement in the child support system. In thirteen years, the agency accrued $£ 3.4$ billion in unrecovered support payments. Consequently, Parliament passed the CMOPA of 2008, which established the Child Maintenance and Enforcement Commission (CMEC), a nondepartmental public body that oversaw the United Kingdom's child maintenance system. By the summer of 2012, the CMEC had failed; almost 1.5 million children were still not receiving adequate support. Therefore, the United Kingdom abandoned the CMEC in July of 2012. On July 31,2012, Parliament promulgated a new enforcement scheme, which transferred responsibility from the CMEC back to the Department for Work and Pensions, now called the CMS. Skinner "Child Maintenance Reforms: Understanding Fathers' Expressive Agency and the Power of Reciprocity" 2013 International Journal of Law, Policy the Family 242; and Ryznar "Two Direct Rights of Action in Child Support Enforcement" 2012-2013 Catholic University LR 1007 1024. For a comprehensive background on child support reform in the United Kingdom, see Wikeley "Child Support Reform in the United Kingdom" (undated) http://www.uea.ac.uk/swp/iccd2006/Presentations/tuespm/ps3\%20 Child\%20support\%20reform/Wikeley/o20ppt.pdf (accessed 2017-04-04). 
expanding range of enforcement powers. ${ }^{91}$ Prior to the Child Maintenance and Other Payments Act of 2008 (hereinafter "CMOP"), the CSA's powers only included deduction from earnings orders (hereinafter "DEOs"); "liability orders" (allowing court action for the forced sale of goods and/or seizure of funds); disqualification from obtaining or holding a driving license, and, imprisonment as a last resort. ${ }^{92}$ Although the CSA did not need court approval to instigate a DEO, it did require it for a liability order. ${ }^{93}$ However, the CMOPA gave new powers to the CSA to improve enforcement efficiency. These powers included removal of the need to apply to the courts for a liability order and for the direct deduction of maintenance from bank accounts. ${ }^{94}$ Other new powers include disqualification from holding or obtaining a passport, imposition of a curfew (up to 12 hours a day) and recovery of arrears from a deceased person's estate. However, all the above powers require an application through the courts. ${ }^{95}$ The CSA or the CMS cannot enforce private arrangements for child support and cannot retrieve any arrears owed before the parent with care started utilising its services. ${ }^{96}$ The CMS introduced enforcement charges for non-payment on the $30^{\text {th }}$ of June $2014{ }^{97}$ These charges are to encourage parents to have their own private arrangements without state involvement. ${ }^{98}$

The CSA or CMS can enforce unpaid maintenance by collecting money from a paying parent's earnings or benefits.99 taking money from a paying parent's bank or building society account; ${ }^{10}$ or by taking court action. ${ }^{11}$ In

1 Skinner 2012 European Journal of Social Security 246.

92 Davidson "Sanctions for Non-recovery of Child Maintenance in the UK" in Curry-Sumner and Skinner (eds) Persistent Problems, Finding Solutions: Child Maintenance in the Netherlands and the UK (2009).

93 The CSA was, however, criticised for not using its enforcement powers, as it tried first to clear the backlog of cases and improve processing times. Wikeley Child Support Law and Policy (2006) 133.

94 See $\mathrm{s} 21$ of the CMOPA.

95 See ss $24,27,28$ and 30 of the CMOPA including the relevant amended ss of the Child Support Act of 1991.

96 United Kingdom Government "Use the Child Maintenance Service and the Child Support Agency (CSA" (undated) https://www.gov.uk/child-maintenance/nonpayment-what-happens (accessed 2017-04-10).

97 These charges are $£ 300$ for liability order; 200 for lump sum deduction order; and £deductions from earnings request/order.

98 This paper is mainly concerned with the statutory maintenance scheme that which involves the CSA or ChMS as well as arrangements through the family courts' system. See Skinner 2012 European Journal of Social Security 233 and 237.

99 The CSA or the CMS can inform the paying parent's employer how much to deduct from their wages. The employer must then pass this to the service and if they refuse, the service can take them to court. If the paying parent gets benefits, a State Pension or War Pension, the amount owed can also be deducted from these payments.

100 The CMS or CSA do not need the court's permission; they can tell the bank or building society to take either regular payments or a one-off payment from the paying parent's account.

101 A paying parent can be taken to court over unpaid child maintenance. The courts can send bailiffs to a paying parent's home to take and sell their belongings to retrieve child maintenance owed; send a paying parent to prison; collect money that's owed to the paying parent by someone else and use this to pay the child maintenance owed; force the sale of a property and use the money to pay the child maintenance owed. If a paying parent attempts to avoid paying by selling property or transferring it to someone else, the service managing 
November 2014, the former Minister of Child Maintenance, Steve Webb and the Department for Work and Pensions announced that from March 2015, subject to parliamentary approval, the CSA and the CMS would begin sharing certain information about the payment records of their clients with credit reference agencies. ${ }^{102}$ This translates to arrear maintenance payments having the same effect on a person's credit score as other debts. Having a poor credit rating can cause people to be refused loans, mortgages, credit cards, hire purchase finance arrangements, mobile phone contracts and other forms of financial credit. Principally, information will be shared about an individual when a liability order is made against them; a measure used as a last resort after other efforts to encourage payment have been exhausted. It is expected that the introduction of the new measure will have a deterrent effect on those who may otherwise choose to evade maintenance payments, thereby attaining adherence to maintenance orders for children and families who require it. Conversely, non-resident parents who have a positive maintenance payment record will be in a position to request that information about their record be shared. Steve Webb once said:

"For too long, a minority of absent parents have got away with failing to pay maintenance, leaving families without that financial support. This government is determined to take action to tackle this kind of irresponsible behaviour and support families."

However, since March 2015 not much has been done regarding reporting of credit defaulters to credit rating agencies. The former Minister openly expressed that the power should be used with circumspection and that the threat of reporting information to credit rating agencies would be enough to make those who had previously failed to pay "do the right thing". ${ }^{104}$ Furthermore, concerns were also raised regarding the efficacy of this measure since sharing information with credit reference agencies depended on a "liability order" from a court: yet the number of applications for these liability orders had decreased substantially in recent years.

The abovementioned enforcement mechanisms are not unique to the United Kingdom. Other developed countries also make use of such enforcement mechanisms. ${ }^{106}$ In light of the above discussion, it seems the United Kingdom Department of Work and Pensions is enforcing orders

their case can request the courts to intervene. The service can also request the courts to reverse any sale or transfer that has already occurred. If action is taken through the courts, the paying parent may have to pay the service's legal costs as well as their own.

102 United Kingdom Government "Pay Child Maintenance or damage your Credit Rating" 5 November 2014 https://www.gov.uk/government/news/pay-your-child-maintenance-ordamage-your-credit-rating (accessed 2017-04-16).

103 Ibid.

104 Albeson "Cracking Down on Parents with Child Maintenance: Why it is Hard to be Optimistic" 27 January 2016 http://blogs.lse.ac.uk/politicsandpolicy/cracking-down-on105 lbid.

106 Skinner 2012 European Journal of Social Sciences 246. For a discussion of maintenance laws of other developed nations, see Martiny "Current Developments in the National Laws of Maintenance: A Comparative Analysis" 2012 European Journal of Law Reform 65. 
against maintenance defaulters in order to ensure that children's rights to maintenance are guaranteed. It seems that the Department and the CMS are willing to protect the rights and interests of vulnerable children. However, it remains for the United Kingdom Parliament to put in place a provision that will provide the CMS with the authority to report information of maintenance debtors to credit rating agencies.

\section{An evaluation of the lessons for South Africa}

The above discussion shows that an effective legal means of enforcing maintenance orders is a problem for many countries including United Kingdom. As is evident from the above, there are numerous challenges faced by the maintenance system, whether it is relating to the content of the maintenance law itself, or simply the poor implementation of the law in the courts. Although in United Kingdom, the Minister of Child Maintenance is legally empowered to share certain information about maintenance defaulters pay, in reality not much has been done regarding reporting of credit defaulters to credit rating agencies. Perhaps South Africa should adopt this flexible approach, which recognizes that the threat of reporting information to credit rating agencies could be enough to make those who had previously failed to pay maintenance to pay. This would ensure that the credit profiling of maintenance defaulters is not spoiled at first instance without giving them proper ventilation for reforming. Indeed, this would ensure that reporting to the credit agencies would be done as a last resort.

Further, as evidenced from the above discussion, the step introduced to provide for the reporting of a maintenance defaulter to any business, which has as its objective the granting of credit, or is involved in the credit rating of persons is not unique to South Africa. Though not much has been done regarding reporting of maintenance defaulters to credit rating agencies, the United Kingdom government has also shown the commitment to do so. It can thus be submitted that South Africa took a step in the right direction in order to ensure that maintenance rights of children and women are enforced.

\section{FINAL REMARKS}

Formulating laws and policies to ensure maintenance debtors pay child maintenance is a demanding exercise. It involves managing numerous competing interests, that is, the state, children and parents, the latter as both individuals and co-parents. On socio-economic and moral grounds, policymakers endeavour to ensure that all maintenance debtors honour their obligations but instead they face high rates of non-compliance, which results in a myriad of enforcement mechanisms that are intended to encourage compliance with maintenance obligations. ${ }^{107}$

107 Skinner 2013 International Journal of Law, Policy and the Family 242. 
This paper focused on the mechanism of reporting maintenance defaulter's failure to pay maintenance to credit rating agencies, a mechanism recently included in the Maintenance Act of South Africa.

South African courts seem to take a more liberal interpretation of the "best interests of children" enshrined in section 28 of the Constitution of South Africa of 1996 particularly in light of their rights to maintenance. Bannatyne; Mngadi; Magewu; Soller among other cases have extended their application and interpretation of the Act to ensure that maintenance payers do not take advantage of the maintenance legal framework in order to evade their obligations. Section 26(2A) of the Act, guards against the reckless extension of credit to maintenance debtors who cannot afford it and encourages those who can afford it to fulfil their obligations timeously.

The South African maintenance enforcement regime is more focused on ex post facto mechanisms rather than preventative measures. It is therefore proposed that the Act should include provisions that encourage payments from the maintenance debtor's bank accounts or employers to prevent default. In addition, section 26(2A) of the Act should be amended to allow both positive and adverse information to be reported to credit rating agencies. This will likely be an incentive for maintenance payers to improve their credit rating.

Other jurisdictions seem, similarly to South Africa, to take a strict approach with maintenance debtors that attempt to abuse the maintenance enforcement system. ${ }^{108}$ Namibia and the United Kingdom are contemplating introducing a quasi-section 26(2A) mechanism in their maintenance enforcement framework. Whether this will occur, is yet to be determined. The Westendorp decision discussed above; section 28 of Bill of Rights, a limitation 109 of respondents' fundamental rights in order to secure for vulnerable children, their life-sustaining legal entitlements, depending on the circumstances of a specific case, would almost certainly be deemed reasonable and justifiable. ${ }^{110}$ The harm caused by the infringement of respondents' fundamental rights is slight in comparison to the beneficial purpose that the limitation is designed to achieve. The fact that section $26(2 \mathrm{~A})$ of the Act as a new measure to ensure that women and children receive the maintenance that is due to them may infringe respondents' fundamental rights should therefore not be seen as a bar to introducing and implementing this measure.

Section 26(2A) of the Act will provide a major deterrent to those debtors who can afford to pay maintenance but fail to do so. Maintenance debtors carry a more onerous obligation compared to ordinary debtors as children who do not usually possess any other means of survival to depend on them. Thus, their payments or non-payments of maintenance debts should reflect on their credit profiles to avoid incurring further obligations that they will not be in a position to honour. In order for Section 26(2A) of the Act to be effective in achieving its purpose, the maintenance orders will need to be

108 See the Canadian Westendorp case par 1.

109 In terms of $\mathrm{s} 36$ of the South African Constitution.

110 Cf De Jong and Sephai 2014 THRHR 215-216. 
adapted to exclude confidential information pertaining to minor children that should not be disclosed. It is important to note that possible implications of section 26(2A) of the Act on the interplay between the latter and the National Credit Act are beyond the scope of this article. It seems that section 26(2A) of the Act is an effective and reasonable measure to encourage maintenance payments by maintenance debtors. However, time will tell whether this assertion holds true. 